Article

\title{
Codependency in the Relations of Couples of Imprisoned Women
}

\author{
Luz Adriana Aristizábal \\ Department of Psychology, Universidad Autónoma de Bucaramanga, Avenida 42 No. 48-11, \\ Bucaramanga 680011, Colombia; aristizabalb@gmail.com
}

Received: 31 July 2020; Accepted: 2 October 2020; Published: 27 October 2020

\begin{abstract}
Female criminal behavior has sparked the interest of many researchers who, from different perspectives, have tried to identify what are the factors that lead them to commit a crime. Studies indicate that female affective bonds change into a potentiator of crime behavior and/or withdrawal of it. The objective of this study was to find out if the couple's bonds (previous or during the prison) were codependent, and to analyze the possible relation between the latter and female crime. This qualitative study used mixed tools in a sample of 27 women in the Bucaramanga prison (Colombia). The I-CO instrument was applied analyzing the four codependency factors: (1) denial mechanisms; (2) incomplete identity development; (3) emotional repression and (4) rescue orientation. The qualitative data obtained through the in-depth interview and focus groups were also analyzed, showing mainly three emerging categories: (1) I did it for him; (2) Although he doesn't love me; and (3) I preferred to remain silent. The results suggested the difficulty of leaving violent relationships and the possible interaction between codependency, violent partner relationships and female crime. This research raises the need to strengthen the empowerment of women inside and outside the prison.
\end{abstract}

Keywords: women; codependency; gender violence; crime; prison

\section{Introduction}

Recent studies point to the increase in women in prison and multiple socio-affective, economic, historical and cultural factors that influence the prevalence of female crime. Several investigations on imprisoned women have demonstrated interesting results based on the socio-historical situation of each region, highlighting the importance of the context in understanding the problem (Giacomello 2013; Wolff and de Moraes 2010; Palma 2011; Salazar 2007). Thus, the processes of criminalization of women are historically and contextually situated (Torres 2008; Almeda 2002), and correspond to the type of relationships that define and re-construct them as social subjects.

Aristizábal and Cubells (2019) argue that women in prison were already imprisoned before entering prison as victims of gender violence, which is generally promoted by their partner (also known as domestic violence). The women arrive in jail escaping from a violent relationship, and in this action of escape they find crime as their only alternative. Therefore, it is considered that there is a clear relationship between being a "victim" and being a "criminal"; a victim of domestic violence and a criminal as the penal system attributes to those who carry out actions contrary to what is established by law and that implies the fulfillment of penalties or sanctions based on the seriousness of the fault in accordance with what is established by the justice system.

For this study, domestic violence is defined as:

"A systematic pattern of abusive behaviors, occurring over a period of time, that may become more frequent and severe and are done for the purpose of control, domination, and/or coercion. Such behaviors may include verbal abuse and threats; physical, psychological and sexual abuse; 
and destruction of property and pets. The batterer frequently accomplishes the abuses in an environment of his own creation that ultimately traps the victim in a state of fear, insolation, deprivation, and confusion. Domestic violence episodes are not random acts of violence of incidents of mere loss of temper. Rather, such episodes are part of a complex, continuing pattern of behaviour, of which the violence is but one dynamic" (Shornstein 1997, p. 1)

Other studies carried out with women who have not been in prison indicate that gender violence is strongly related to emotional dependence (Aiquipa 2015; Moreno and Osorio 2013; Echeburúa et al. 2002). De Miguel Calvo (2012, 2016), Chamberlen (2017) and Lagarde (1990), have analyzed the lifestyles of women in prison and have denoted addictions and emotional dependence as factors that describe them.

Aristizábal (2017) also relates the power of affective bonds to mobilize women's behavior towards crime and/or withdrawal; among them, the links with the couple are prioritized as the relationship that has the greatest influence in the commission of the crime. As the author mentions, affective bonds refer to any process of relationship given between subjects and/or social objects, marked by an emotional charge that attributes its own meanings and that mobilizes the action of the parts (or one of the parts) that relate to each other (Aristizábal 2017). These could also be determined as a space available for gender violence, which can be considered as a type of psychosocial prison in which women find themselves before being captured.

Such a psychosocial prison may correspond to emotional dependency, defined by Momeñe et al. (2017) as a need for continuous affection and continuous and excessive contact with the partner, and that usually the women had greater emotion regulation difficulties with than men. Likewise, other studies indicate that the satisfaction of the relationship of the couple is significantly explained by their emotional dependency, perceptions of interpersonal rejection and unrealistic relationship expectations (Kemer et al. 2016), that could be reflect the limitations of a psychosocial prison.

Some authors make a difference between emotional dependency and codependency. Noriega and Ramos (2002) affirm that codependency is a disorder in the area of interpersonal relationships (more often in the couple) that refers to a psychological problem that occurs repetitively in almost everyone who lives with an addicted person (any type of addiction that is usually attributed to alcoholism). Freixa (2000) point out that codependency occurs through a process that progressively increases in parallel to the couple's addiction problem, which fluctuates between stable episodes and despair in the face of the disability of not achieving change in their relationship. Thus, codependent relationships are characterized by self-perceptions, attitudes and unhealthy behaviors that, instead of reducing problems, increase them. Codependent people generally come from dysfunctional families or with some addiction behavior, and therefore in the relationship with their partner they tend to allow such patterns (Woititz 1993).

Other studies denote that codependency is a syndrome that encompasses different symptoms and personality traits, in which the individual is affected by having been or by being immersed in a family environment with a long history of addictions (alcohol, drugs, among others), or in stressful environments (Potter-Efron and Potter-Efron 1989). This is related to what was mentioned by Aristizábal and Cubells (2017), referring to the fact that women with criminal histories behavior have histories of mistreatment and/or abuse that have developed throughout their lives and many are involved in addictions that have been gestated from childhood. In this way, it can be said that a person is codependent because they maintain a relationship with a partner who abuses them, violates them in some way or exploits them. Codependent people structure their lives around subjects with some type of addiction, establishing a strong commitment, despite the failures and multiple frustrations that this relationship causes them (Wright and Wright 1991). According to Noriega and Ramos (2002), codependency occurs more frequently in women than in men, this could be considered as a strategy for coping with the crisis, stressful environments and/or situations that make them vulnerable to threat. In the case of men, according to Roehling et al. (1996), conduct disorders turn out to be the coping strategy in the face of their own crises. 
So far, there is no known study that has analyzed the codependency in intimate relationships in imprisoned women in depth, much less that has determined whether it establishes any type of relationship with criminal activity. Inviting imprisoned women to dialogue on the topic of discussion can become a narrative strategy that empowers them, as it leads them to think more deeply about their relationships with men and how that led to their imprisonment, contributing to the withdrawal and the assumption of gender equality from their own practices. Therefore, it is necessary to identify whether or not there is a relationship between female crime and codependency in couple relationships and to analyze the forms of production and reproduction of these relationships.

\section{Materials and Methods}

This qualitative study uses qualitative and quantitative instruments such as the in-depth interview, the focus groups and the psychological test ICOD Test MP92-100 (Noriega 2011), respectively. It is framed within the socio-constructionist (Ibáñez and Jiménez 2001) and gender (Harding 2004; Pujal 2005) perspectives.

\subsection{Sample}

Intentional sample made up of 27 internal women in the Women's Prison of Bucaramanga (Colombia), who voluntarily decided to participate in this study and have been part of the "BONDINGS" program since 2018 (BONDINGS-Affective Bonds NGO 2020). It was essential that all the participants reported having a partner before and/or during the process of entering the prison. Women's personal data are reserved and, therefore, the identification code created for this study is used: from S-1 to S-27 (women registered on lines 1 to 27 in the database).

\subsection{Procedure}

(1) The information from this study was shared with all the women invited to participate and the voluntary decision was registered by signing the informed consent. (2) The ICOD emotional codependency instrument was applied and the four codependency factors in women deprived of liberty were analyzed. (3) In-depth interviews were carried out through the narrative design of the topic and focus groups, emphasizing the exploration of the couple's bond. (4) The data were analyzed to find out the forms of production and reproduction of codependency and, from their own discourses, contribute to the empowerment of women in the reduction of violence and thus gender inequality. (5) The participants will know the results of this study once the entry to prison is made possible again, which has been stopped due to preventive care of the COVID-19 pandemic. This research process began in 2019.

\subsection{Instruments}

ICOD MP92-100 test (Noriega 2011), in-depth interviews and focus groups. For the application of the test, the intention of evaluating the couple's relationships before and/or during admission to prison was specified.

\subsection{Data Analysis}

The data collected through the ICOD MP92-100 were descriptive and analyzed through the SPSS software (IBM SPSS Statistics 27-Bucaramanga, Colombia). For the data resulting from the interviews and the focus groups, the analysis of the discourse was carried out through the Atlas.Ti software (The Qualitative Data Analysis 8-Bucaramanga, Colombia). The interviews were transcribed through Scribe Transcription Software, following the criteria of Jefferson (2004). 


\section{Results and Discussion}

Initially, the results of the emotional codependency test (ICOD MP92-100) were analyzed, finding that $88.9 \%$ of the participating women presented emotional codependency with the couples they had before and/or during prison admission, with a score higher than 32 according to the descriptive analysis parameters. The test analyzed the four conceptual dimensions of codependency proposed by Noriega (2011): Factor 1. Denial mechanisms; Factor 2. Incomplete development of identity; Factor 3. Emotional repression and Factor 4. Rescue orientation towards others.

The instrument applied in the Bucaramanga Women's Prison yielded very approximate values in each of the factors; however, $33.33 \%$ of the sample obtained the highest score in factor 4: rescue orientation, where the woman tries to control her environment seeking to solve problems of others; with attitudes of perfectionism, excessive work and exaggerated responsibility. This confirms what has been exposed by different authors, who point out that there are women who assume a traditional gender role, mainly associated with caring for others (Lagarde 1990; Lamas 1996).

Subsequently, $25.93 \%$ of the participants obtained a high score in factor 2: incomplete development of identity. According to Noriega (2011), this factor corresponds to a child development interrupted by dysfunctional situations, where women since childhood take a role of early responsibility, while reversing the role of father or mother with their own parents and being trapped in a unresolved symbiosis with them, waiting one day to meet their own needs for support, care and protection. Therefore, the woman with an incomplete identity development lives in order to meet the needs of others as a way to compensate for her own feelings of fear and insecurity and it is generally difficult for her to make decisions because internally she feels incomplete.

In the third instance, factor 3 was found: emotional repression, with a $22.22 \%$ frequency in the sample. Here, women do not usually express their displeasure and/or emotions because they fear causing problems and losing acceptance of others, trying to be understanding and accommodating to everyone, living in fear that something terrible may happen. Finally, factor 1 appears: denial mechanism with a $18.52 \%$ occurrence. This factor manifests itself as a defense mechanism that seeks to avoid experiencing a reality that is difficult to face. It manifests itself with self-deception and justifications, through which the woman disqualifies her thoughts and emotions, while avoiding contact with other people who may confront her with her reality. It is generally made visible by tolerating mistreatment of the couple, avoiding contact with other people so as not to listen to their opinions, confusion when trying to accept what they do not really accept, justifying their partner's faults and minimizing problems with their partner so as not to have to solve it.

The quantitative data presented above were closely related to the qualitative data analyzed through in-depth interviews and focus groups. The speeches of the participating women clearly show the social construction of what it means to "be a woman" in a patriarchal society that links her to caring for others; care that is often permeated with violence. Most of the women tried to leave their violent partners and they did not succeed until they got to prison; once there, many men walked away from them and other women still continue with this type of relationship that from prison becomes ideal because the daily violence is hidden and the expectation is generated that when they leave "everything will change", and even "it will be better than before". Below are some emerging categories that confirm the conceptual factors of codependency and that, in turn, show a possible connection between codependency and female crime.

\subsection{Did It for Him}

Many women repeatedly expressed in their stories the statement: "I did it for him," indicating an attitude of fidelity, rescue and help towards their partner, who expressed how much they needed them, and who perceived themselves as vulnerable subjects. Most of the women were victims of domestic violence, although they did not identify emotional abuse and physical assault as violent actions. Some men were not only aggressive, but also dependent on alcohol, drugs, or gambling. 
This category is closely related to factors 4 and 2 of codependency: rescue orientation and incomplete identity development.

"He needed me ... , I knew that if I left him he would not bear it ..., because he told me [ ... ] Everything I did I did for him, for a better future, because I kept hoping that someday he was going to stop drinking, and I saw that he was trying. When we were well he did not get drunk, but if we had a fight he would leave [... ] The same thing happened to me with my dad" (S-22, Woman registered on line 22 of the database)

Original version:

“El me necesitaba ..., yo sabía que si yo lo dejaba él no lo iba a soportar ... , porque él me lo decía [ ... ] Todo lo que hice lo hice por él, por un futuro mejor, porque yo guardaba la esperanza de que algún día iba a dejar de tomar, y yo veía que lo intentaba. Cuando estábamos bien no se emborrachaba, pero si teníamos alguna pelea de una se iba [ ... ] Lo mismo me tocó con mi papá" (S-22, Woman registered on line 22 of the database)

"I did everything for him ... , I fell madly in love ... [ . . ] I blindly trusted him and worried about his things, so that he was well [ ... ] He never hit me, but the worst thing he could have done was send me to coordinate the robbery while he stayed directing it from home... I did it for him, so that he was well" (S-8, Woman registered on line 8 of the database)

Original version:

"Yo le hacía todo ... , me enamoré perdidamente ... [ ... ] Yo confiaba ciegamente en él y me preocupaba por sus cosas, porque estuviera bien [ ... ] Él nunca me pegó, pero lo peor que me pudo haber hecho fue mandarme a coordinar el robo cuando él se quedaba dirigiendo desde la casa ... Lo hice por él, para que él estuviera bien" (S-8, Woman registered on line 8 of the database)

Caring for the other turned out to be an explanatory factor of female crime (Aristizábal and Cubells 2017). According to Gilligan (1982), the role of women is framed in the ethics of caring for other people-a responsibility that is socially conferred and for which she is demanded. In other words, it is a woman's desire to meet their partners' needs (through crime) while neglecting their own needs; it is the socially imposed commitment to prioritize the requirements of others over one's own. Based on this responsibility that is founded in a patriarchal society, women face the crossroads of looking after the well-being of the other, although many times they have to go against social, moral and legal norms.

\subsection{Although He Doesn't Love Me}

Affective dependency is characterized by emotional distress (insecure attachment) and dependency to another person with a low self-esteem and reassurance need (Scantamburlo et al. 2013). This is clearly observed in the stories of several women interviewed, who affirm the need to be with someone even though he does not show them that he loves them. Many allowed the mistreatment as a way of "not enlarging the problem", at the cost of the companionship benefit. This category is closely related to co-dependency factor 1 on denial mechanisms.

"One already gets used to the other person and well ... finally one resigns oneself to the things that happen as they have to happen ... In the end we did not touch each other, nor speak, nor look at each other ... At first I cried a lot, but afterwards I said that it was not worth crying, so I resigned myself [ ... ] We continue to live together because I did not want to be alone, and the truth is that I did not see myself alone, I was never alone, ever since I was little there was someone, although if only to make a bulk" (S-10, Woman registered on line 10 of the database) 


\section{Original version:}

"Uno ya se acostumbra a la otra persona y pues ... finalmente uno se resigna a que las cosas pasen como tienen que pasar [ ... ] Ya a lo último él ni me tocaba, ni me hablaba, ni me miraba ... Al principio lloré mucho, pero ya después dije que no valía la pena llorar, entonces me resigné [ ... ] Seguíamos viviendo juntos como por no estar sola, y pues la verdad yo no me veía sola, es que nunca estuve sola, desde chiquita siempre había alguien, aunque solo sea para hacer bulto" (S-10, Woman registered on line 10 of the database)

As mentioned by Scantamburlo et al. (2013), overprotective and authoritarian parenting and cultural and socio-environmental factors may contribute to the development of a dependent personality. Psychological epigenetic factors, such as early socio-emotional trauma, could imprint on neuronal circuits in prefrontal-limbic regions that are essential for emotional behavior. According to the authors, there is a strong relationship between dependent personality, domestic violence, and addictions. Therefore, the restoration of self-esteem and therapeutic strategies focused on autonomy are essential.

"He spoke to me when he felt like it, and when he didn't, he would not. He never hit me, but sometimes I preferred to be hit rather than ignored. He would sit in front of the television and pretend nothing else existed" (S-19, Woman registered on line 19 of the database)

Original version:

"Él me hablaba cuando se le daba la gana, y cuando no, no. Él nunca me llegó a pegar, pero a veces prefería que me pegara a que me ignorara. Él se sentaba frente al televisor y hacía como si nada más existiera" (S-19, Woman registered on line 19 of the database)

As evidenced in the stories, the women interviewed were being affected by gender violence and affective dependency. Recognizing that "gender violence is an issue that shows patriarchal practices in all its forms of manifestation" (Madera-Hernández and Herrera-López 2010, p. 88), it is assumed that couple relationships are the direct sample of such manifestations of violence. This type of violence, sometimes referred to as marital violence, domestic violence, violence by intimate partner, etc., affects not only women, but their different fields of action, such as family, work, and social (Ocampo and Amar 2011), and therefore it is not a problem that corresponds to singular situations, but a social one, and with multiple factors that interact with each other until inducing crime. These factors are closely related to family life, such as marital violence, physical punishment and affection received from parents, where the interests and/or expectations that bind them to the couple strengthen and maintain these power relationships (González and Santana 2001).

Intimate partner violence is a social problem that affects a large number of women (many without recognizing it as acts of violence), where a higher prevalence of psychological violence rather than physical and sexual violence is observed, and where in many cases they occur simultaneously (Martínez 2003). According to Cantera and Blanch (2010), one cannot ignore the great influence exerted by social stereotypes on gender (male provider, female caregiver), as promoters of intimate partner violence, given in a patriarchal society that demarcates the norms of action expected of the couple; in other words, women are legitimized to obey and follow the social demands that bind them to their partner in a condition of dependency. In this patriarchal order, norm and justice have been built from the analysis of a male subject that often suppresses the female subject in any of its forms of expression (Almeda 2017).

Estimating the relationship between codependency and female crime implies adding the category of gender violence to the duo. Palma states that, socially, it has been established that women commit crimes that are more related to passive and non-aggressive acts, since they are expected to be the promoters of social or communal good and not, on the contrary, those that affect this security (Palma 2011). This connection of women to the category of the fragile, the careful, and the maternal leads them to be judged by society with moral and exclusive restrictions that are termed as bad, dangerous and harmful. In this line, we could not see the unequal particularities between men and women, without 
looking at the context in which they are built, since it is in that same context that they change, transform, negotiate and realize the plurality of practices of daily life (Lamas 2003). According to this study, couple relationships are the socio-affective space in which the greatest violent practices take place.

Such violent practices are pronounced in codependent relationships that strengthen over time as a couple's addiction problem also increases; a fact that many times is not recognized by the affected subject. This relationship fluctuates between stable episodes and despair in the face of the disability of not achieving change in their relationship (Noriega and Ramos 2002; Freixa 2000). In this way, codependency is a multicausal problem (as it is spoken of crime), that appears and reproduces in power relations that make women vulnerable. This category is visible in women in prison, which also turns out to be a gender issue. In other words, gender is a discursive effect, a result of a set of identity regulatory practices that can face problems due to codependent relationships, which in turn limit them and often lead down wrong paths such as crime (as is the case of the participants in this study).

\subsection{Preferred to Remain Silent}

This category is closely related to codependency factor 3: emotional repression. Some women were understanding and accommodating to their partners, did not express their thoughts and emotions out of fear of being rejected or losing control of themselves, or even losing the relationship. As Momeñe et al. (2017) affirm, psychological abuse and difficulties in regulating emotions are predictors of emotional dependence.

"Sometimes I kept quiet to avoid problems ... because I knew that if I started talking I would despair and if I didn't end up crying like crazy, then I did other crazy things ... and he despairs of seeing me cry exasperates him ... " (S-14, Woman registered on line 14 of the database)

Original version:

"Yo a veces me quedaba callada para evitar problemas ... pues yo sabía que si yo comenzaba a hablar me iba a desesperar y si no terminaba llorando como una loca, entonces hacía otras locuras ... y a él le desespera verme llorar ... " (S-14, Woman registered on line 14 of the database)

Past studies have looked at the relationship between emotional dependency, the occurrence and sustainability of abuse and the low probability that a victimized person will terminate a relationship. Individuals with Dependent Personality Disorder or with dependent characteristics present a higher risk of becoming abusive (both physically and mentally) as well as becoming a victim of abuse (both physically and mentally), as in the S-14 interviewee "then did other crazy things", as well as becoming victims of abuse "Sometimes I kept quiet to avoid problems" (Leemans and Loas 2016). Some interviewed women were aware of their emotional dependence, naturalized it and generalized it "that happens to all of us"-reasons that perhaps explain the difficulty in walking away from these violent relationships. Porto and Bucher-Maluschke (2012) identified economic and emotional dependencies as the main determinants of the permanence of some women in violent situations, in addition to the secondary gains they could obtain from these relationships.

In conclusion, we are faced with a great social problem: codependent relationships. The latter, mediated by gender violence, can stimulate escape behaviors such as crime in women. Trying to get out of the psychosocial prison from a violent and dependent relationship, they arrive at the physical prison. It is also necessary to know that emotional dependency is one of the four most common causes of femicide: (1) badly managed male aggressivity; (2) slavery in human relationships; (3) various forms of jealousy; and (4) emotional dependency (Pasini 2016), which alerts the prioritization of this problematic nucleus on public programs.

Likewise, psychological and emotional dependence is associated with addiction to tobacco and/or other elements (Liaquat et al. 2016), which represents a new challenge for clinical research regarding its management. Some interviewed women were addicted to some psychoactive substance. A strong 
belief exists among addiction treatment specialists that the primary reason addicts remain addicted is less about pleasure-seeking and more about their need to escape and dissociate from the pain of his or her (often trauma-based) emotional isolation. In short, all human beings deeply crave intimate, dependable, empathetic relationships. Addicts, however, have learned, typically through traumatic experience, that others cannot be trusted to reliably meet their need for intimate connection. Essentially, they learn to fear emotional vulnerability, and they therefore distance themselves from other people, turning instead to addictive substances and/or behaviors as a way to "not feel" their unmet emotional dependency needs. As such, a primary part of treating addicts, regardless of the nature of their addiction, is helping them develop healthy and supportive emotional bonds (Weiss 2016).

In addition, some of the women participating in this study showed characteristics of the "Fortunata syndrome" (Mairal 2015), repeatedly establishing affective relationships with married men. Some behaviors and attitudes were identified such as emotional dependence and strong and lasting loyalty to the man, ambivalence feelings towards the official partner (resentment), questioning the validity of the man's union with the other woman and repeated one's fantasies that their circumstances would change and they would end up being together.

Finally, in accordance with what was exposed by Petruccelli et al. (2014), it can be said that sociocultural and demographic variables, together with the previous structuring of attachment styles, help to determine the scope, frequency and intensity of the demands made on the couple, as well as to feed fears of loss, abandonment or betrayal (Petruccelli et al. 2014), which gives us a clear picture for a deep understanding of codependent relationships, answering the question: why do some women not leave violent relationships? There is an answer.

Based on all the above, it could be said that: (1) the effects of domestic violence can be used by perpetrators to coerce women to commit crimes; (2) The effects of codependency can lead women to make active decisions in participating in crime to meet the needs of their partners; (3) There is a strong relationship between the effects of domestic violence and the effects of codependency that could be studied in depth in subsequent studies: post-traumatic stress, anxiety, depression, low self-esteem, feelings of guilt, shame, social isolation, feelings of mistrust and hostility, suicide attempts, among others; (4) Domestic violence and codependency could be considered as psychosocial prisons that restrict freedom of expression and decision for those who assume them; (5) The women participating in this study recognized that they were manipulated to participate in crime, but that at the time they were not aware of it. In other words, none of them felt forced to commit the crime, only until they got to prison; a situation that signals an alert in all women who are being victims of domestic violence and have developed a codependent relationship. It is clear that women who comply with these last two factors are vulnerable to committing a crime and/or any other action that threatens their integrity and that of others. It is not necessary to go to prison to take action on the matter.

\section{Conclusions}

The results of this study clearly point to the profile of emotionally codependent women to their partners; codependency that is described as a type of prison that goes beyond physical prison. Many of the women interviewed were incarcerated before entering prison, suppressing themselves in order to live through their partners. Some women left the violent relationship when they were captured, others have persisted, so a new question arises: what is the difference between those who decided to break the violent relationship and those who decided to continue? It is clear that breaking the violent relationship does not mean that they have closed the cycle of emotional dependency, so who really finished the circle of dependency? Some women closed the circle of dependency a long side the process of this study, others did so from the consolidation of new practices of subjectivation that led them to identify themselves as valuable, autonomous people and with the agency to make adjustments and changes for their good and the common good.

This study revealed the strong relationship that exists between emotional codependency and violent relationships. People who are emotionally dependent on other people (who in turn have 
another type of dependency) establish a difficult cycle to break, because they are generating certain practices that place the responsibility of their previous dependency on the couple, that is, specifically certain guilt over their own vulnerability, and therefore they demanded the couple's rescue. In this relationship of emotional codependency, arguments are produced that erroneously justify the actions of the other and their own, to the point that it becomes difficult to modify them or look for other options. Codependency is a form of violence in that it limits the freedom of choice.

In this study, it is estimated that one of the ways to break the argument that justifies codependency is through another argument that turns out to be more convincing than the first. It is not enough that it is a valid and justifiable argument for other people if it lacks validity for oneself. From here, it is clearly seen how subjective violence is, although in itself it has such objective characteristics through which it can be determined whether or not someone is a victim of violence. Because the way of perceiving violence is subjective, the way out of a violent relationship is also very subjective. It is increasingly complex to identify a unique pattern that indicates the level of vulnerability of a woman to fall into a violent relationship and the level of empowerment to leave it.

Despite subjective limitations to objectify knowledge, this study provided valuable data on the possible ways out to leave a violent relationship. It is clear that knowing this route was not the main objective of this study, but when observing what was happening with women in the process, and the impact that the activities had on them, in the visibility of codependency, the identification of gender violence and finally the voluntary decision to break the violent circle allowed to us identify a series of steps that, although they had unique aspects, manifested themselves in several of them.

In the first instance, the identification of the primary codependency factor that is established in a relationship in a repetitive way is necessary. This study made it many times easier to identify if the couple has a dependency and if they have dependent behaviors towards the couple, to identify whether or not they are victims of gender violence. Many interviewed women indicate that they have never had any type of violence, but that they have generated emotional dependencies of men with dependence on alcohol, gambling, sex, among others (reviewing their past-present).

Once the level of codependency is identified, the harmful effects on their life and the lives of their close ones should be reviewed concerning their mental health and their quality of life. At this point, women were constructing their own arguments about how profitable it was to sustain this codependent relationship in relation to cost-benefit (reviewing their present). Some women did not want to continue on the following topics for discussion, some stayed in the review of their past and a bit of the present, but they gave up on the process. Some of them expressed that they did not want to talk about their injuries; in confinement they preferred to think about the ideal of a romantic relationship, because they did not want to be alone. It is here where the metaphor of psychically imprisoned women is visible: women transit from one jail to another-from the jail of dependency to the jail of fear of loneliness among many others.

Third, they were allowed to identify the repercussions in the future if they continued in this type of relationship (reviewing their future). Finally, those who continued the process reached the last stage of this discussion strategy: painful but decisive decisions. Each participant was led to reflect on possible decisions that approach the woman they want to be and not the one others compel or want to see. This process cannot stop here; many of these women revealed the presence of other bonds that motivated their own agency.

Based on the above, it is necessary to continue deepening the study of affective bonds, their impact, and the practices that link the consolidation of healthy, liberating, empowering and transforming bonds, as well as in the personal agency strategies that usually occur from the modifications in the perception of life and the environment. It seems that recent generations build prisons that provide them with some fake security; there are women fearful of resistance, of defiance, of loneliness, with the uncertainty of tomorrow, weak in the face of threat and fragile in the face of failure. However, just as there are these types of women, there are also women who are characterized by having healthy, non-violent, non-dependent relationships, women who are not afraid of suffering, who work tirelessly for their 
present and future, who do not stop at defeat but assume that this could be a chance for success, so as not to continue building bars of psychic prisons that could only be demolished with arguments based on the truth of themselves, a truth that perceives us all as beings equally worthy of love.

Funding: This research was funded by Universidad Autónoma de Bucaramanga-UNAB, grant number 056.

Acknowledgments: To the women who voluntarily decided to participate in this study sharing their life stories and participating all research activities. To UNAB for financing this research process.

Conflicts of Interest: The author declares no conflict of interest. The funder had no role in the design of the study; in the collection, analyses, or interpretation of data; in the writing of the manuscript, or in the decision to publish the results.

\section{References}

Almeda, Elizabeth. 2002. Corregir y castigar: El ayer y hoy de las cárceles de mujeres. Barcelona: Ediciones Bellaterra. Almeda, Elizabeth. 2017. Criminología feministas, investigación y cárceles de mujeres en España. Papers 102: 151-81. [CrossRef]

Aiquipa, Jesús Joel. 2015. Dependencia emocional en mujeres víctimas de violencia de pareja. Revista de Psicología 33: 411-37. [CrossRef]

Aristizábal, Luz Adriana. 2017. Prácticas Sociales que Promueven el Delito y/o el Desistimiento en Mujeres Privadas de la Libertad. Ph.D. thesis, Universidad Autónoma de Barcelona, Barcelona, Spain. Available online: https://hdl.handle.net/10803/457745 (accessed on 29 July 2020).

Aristizábal, Luz Adriana, and Jenny Cubells. 2017. Delincuencia Femenina y Desistimiento: Factores Explicativos. Universitas Psychologica 16: 1-14. [CrossRef]

Aristizábal, Luz Adriana, and Jenny Cubells. 2019. Impact of Partner Violence on Female Delinquency. Social Sciences 8: 32. [CrossRef]

BONDINGS-Affective Bonds NGO. 2020. Liberating Affective Bonds. Available online: www.bondings.org (accessed on 29 July 2020).

Cantera, Leonor M., and Josep Blanch. 2010. Percepción Social de la Violencia en la Pareja desde los Estereotipos de Género. Psychosocial Intervention 19: 121-27. [CrossRef]

Chamberlen, Anastasia. 2017. Changing bodies, ambivalent subjectivities and women's punishment. Feminist Criminology 12: 125-44. [CrossRef]

De Miguel Calvo, Estibaliz. 2012. Relaciones amorosas de pareja en las trayectorias vitales de las mujeres encarceladas. Ph.D. thesis, Universidad Ureka en el país Vasco, Leioa, Spain. Available online: http: //hdl.handle.net/10810/11331 (accessed on 15 July 2020).

De Miguel Calvo, Estibaliz. 2016. Relaciones amorosas de las mujeres encarceladas. Leioa: Universidad del País Vasco/ Euskal Herriko Unibertsitatea.

Echeburúa, Enrique, Paz de Corral, and Pedro J. Amor. 2002. Mujeres maltratadas en Convivencia prolongada con el agresor: Variables relevantes. Acción Psicológica 2: 135-50.

Freixa, Francesc i Sanfeliu. 2000. La reconsideración de las experiencias adversas de los que conviven con un alcohólico/a como recurso socioterapeútico: Un hito a asumir, la codependencia. Revista Española Drogodependencias 25: 235-41.

Giacomello, Corina. 2013. Mujeres, delitos de drogas y sistemas penitenciarios en América Latina. London: IDPC.

Gilligan, Carol. 1982. In a Different Voice: Psychological Theory and Women's Development. Cambridge: Harvard University.

González, Rosaura, and Juana Dolores Santana. 2001. La violencia en parejas jóvenes. Psicothema 13: 127-31.

Harding, Sandra. 2004. The Feminist Standpoint. Theory Reader. New York: Routledge.

Ibáñez, Tomás, and Bernardo Jiménez. 2001. Psicología Social Construccionista. Guadalajara: Universidad de Guadalajara.

Jefferson, Gail. 2004. Glossary of transcript symbols with an introduction. In Conversation Analysis: Studies from the First Generation. Edited by Gene H. Lerner. Philadelphia: John Benjamins, pp. 13-23.

Kemer, Gülşah, Gökçe Bulgan, and Evrim Çetinkaya Yıldız. 2016. Gender Differences, Infidelity, Dyadic Trust, and Jealousy among Married Turkish Individuals. Current Psychology 35: 335-43. [CrossRef] 
Lagarde, Marcela. 1990. Los cautiverios de las mujeres: Madresposas, monjas, putas, presas y locas. México: Universidad Nacional Autónoma de México, Colección Posgrado.

Lamas, Marta. 1996. El Género. La construcción cultural de la diferencia sexual. Mexico: Porrúa.

Lamas, Marta. 2003. Género: Claridad y Complejidad. Mexico: Mimeo.

Leemans, C., and G. Loas. 2016. On the relationship between emotional dependency and abuse [La relation entre la dépendance affective et la maltraitance]. Revue Medicale de Bruxelles 37: 79-86. [PubMed]

Liaquat, Nida, Abdul Majeed Jaffar, Muhammad Zeeshan Haroon, Muhammad Bilal Khan, and Hammad Habib. 2016. Knowledge and Perception of areca/smokeless tobacco users about oral cancer. Journal of Ayub Medical College 28: 164-67. [PubMed]

Madera-Hernández, Yenia, and Maritza Herrera-López. 2010. La violencia de género en la relación de pareja. Panorama Cuba y Salud 5: 88-90.

Mairal, Jorge Barraca. 2015. The "Fortunata syndrome": A form of emotional dependency. Papeles del Psicologo 36: $145-52$.

Martínez, Lucía. 2003. La violencia de género en la relación de pareja ¿una cuestión no perceptible en la vida cotidiana? Revista de Ciencias Sociales 9: 235-51.

Momeñe, Janire, Paula Jáuregui, and Ana Estévez. 2017. The predictive role of psychological abuse and emotional regulation in emotional dependency | [El papel predictor del abuso psicológico y la regulación emocional en la dependencia emocional]. Behavioral Psychology/Psicologia Conductual 25: 65-78.

Moreno, Martha J. V., and Natalia S. Osorio. 2013. Dependencia emocional en un grupo de mujeres denunciantes de maltrato de pareja. Textos y Sentidos 7: 10-29.

Noriega, Gloria. 2011. Instrumento de Codependencia-ICOD. Mexico: Manual Moderno.

Noriega, Gloria, and Luciana Ramos. 2002. Construcción y validación del instrumento de codependencia (ICOD) para las mujeres mexicanas. Salud Mental 25: 38-48.

Ocampo, Luz Elena, and José Juan Amar. 2011. Violencia en la pareja, las caras del fenómeno. Salud Uninorte 27: 108-23.

Palma, Claudia. 2011. Delito y sobrevivencia: Las mujeres que ingresan a la cárcel el buen pastor en Costa Rica por tráfico de drogas. Anuario de Estudios Centroamericanos 37: 245-69.

Pasini, Willy. 2016. Femicide: Psychodynamic aspects | [Le féminicide: Aspects psychodynamiques]. Sexologies 25: 7-10. [CrossRef]

Petruccelli, Filippo, Pierluigi Diotaiuti, Valeria Verrastro, Irene Petruccelli, Roberta Federico, Giovanni Martinotti, Andrea Fossati, Massimo Di Giannantonio, and Luigi Janiri. 2014. Affective dependence and aggression: An exploratory study. BioMed Research International 2014: 805469. [CrossRef] [PubMed]

Porto, Madge I., and Júlia S. N. F. Bucher-Maluschke. 2012. Violence, women and psychological care in the amazonia and the distrito federal | [Violência, mulheres e atendimento psicológico na amazônia e no distrito federals]. Psicologia em Estudo 17: 297-306. [CrossRef]

Potter-Efron, Ronald T., and Patricia S. Potter-Efron. 1989. Assessment of codependency with individuals from alcoholic and chemically dependent families. Alcoholism Treatment Quarterly 6: 37-57. [CrossRef]

Pujal, Margot. 2005. El feminisme. Barcelona: UOC.

Roehling, Patricia V., Nikole Koelbel, and Christina Rutgers. 1996. Codependence and conduct disorder: Feminine versus masculine coping responses to abusive parenting practices. Sex Roles. A J Reserach 35: 603-16. [CrossRef]

Salazar, Teresa. 2007. Análisis sobre la delincuencia femenina por droga: Centro penitenciario los Andes. MéridaVenezuela. 2005-2006. Capítulo Criminológico 35: 539-62.

Scantamburlo, G., W. Pitchot, and M. Ansseau. 2013. Affectice dependency [La dépendance affective]. Revue Medicale de Liege 68: 340-47.

Shornstein, Sherri L. 1997. Domestic Violence and Health Care. Thousand Oaks: SAGE Publications.

Torres, Andreina. 2008. Drogas, cárcel y género en Ecuador: La experiencia de mujeres mulas. Quito: FLACSO-Ecuador.

Weiss, Robert. 2016. Why do people with addictions seek to escape rather than connect? A look at the approach to addiction treatment. Consultant 56: 786-90.

Wolff, Maria Palma, and Márcia Elayne Berbich de Moraes. 2010. Mulheres e tráfico de drogas: Uma perspectiva de género. Revista Brasileira de Ciencias Criminais 18: 375-95. [CrossRef]

Woititz, Janet Geringer. 1993. Hijos Adultos de Padres Alcohólicos. Mexico: Diana. 
Wright, Paul H., and Katherine D. Wright. 1991. Codependency: Addictive love, adjustive relating, or both? Contemporary Family Therapy 13: 435-54. [CrossRef]

Publisher's Note: MDPI stays neutral with regard to jurisdictional claims in published maps and institutional affiliations.

(C) 2020 by the author. Licensee MDPI, Basel, Switzerland. This article is an open access article distributed under the terms and conditions of the Creative Commons Attribution (CC BY) license (http://creativecommons.org/licenses/by/4.0/). 